\title{
Viscoelastic behavior during the ripening of a commercial low-fat soft cheese
}

\author{
Bárbara E. MezA ${ }^{1}$, Roxana A. VerdinI ${ }^{1,2}$, Amelia C. RubIolo ${ }^{1 *}$ \\ ${ }^{1}$ Instituto de Desarrollo Tecnológico para la Industria Química (INTEC), Consejo Nacional \\ de Investigaciones Científicas y Técnicas (CONICET), Universidad Nacional del Litoral (UNL), \\ Güemes 3450, 3000 Santa Fe, República Argentina \\ ${ }^{2}$ Departamento de Química Analítica, Facultad de Ciencias Bioquímicas y Farmacéuticas, \\ Universidad Nacional de Rosario (UNR), Suipacha 531, Rosario 2000, República Argentina
}

\author{
Received 28 April 2009 - Revised 24 January 2010 - Accepted 25 January 2010 \\ Published online 18 March 2010
}

\begin{abstract}
The change in the viscoelastic behavior over ripening of a commercial low-fat soft cheese was investigated. Twelve low-fat soft cheeses that contained microparticulated whey proteins as fat mimetics (Simplesse ${ }^{\circledR}$ ) were obtained from a local factory and stored at $6{ }^{\circ} \mathrm{C}$. Three of these cheeses were sampled at 1, 21, 48 and 76 days of ripening. Physicochemical properties such as $\mathrm{pH}$, moisture content, salt concentration and maturation index (MI) were determined. Frequency sweeps were performed in the range of $0.01-10 \mathrm{~Hz}$ at $20{ }^{\circ} \mathrm{C}$ and the region of linear viscoelasticity was determined by performing stress sweeps. Frequency dependence of elastic and viscous moduli was modeled using the power-law and Maxwell equations. The initial moisture content was $52.80 \pm 0.46 \%$ and did not change significantly during ripening. Salt concentration on day 1 was $0.41 \pm 0.01 \%$ and increased significantly during maturation. The $\mathrm{pH}$ decreased from $5.27 \pm 0.03$ on day 1 to $5.11 \pm 0.03$ by day 48 while the MI increased from $3.60 \pm 0.67$ on day 1 to $8.66 \pm 1.05 \%$ by day 48 . Low-fat soft cheese containing whey proteins behaved as a linear viscoelastic material during dynamic testing at stresses below $630 \mathrm{~Pa}$. In general, viscoelastic parameters derived from both models decreased with ripening time and at the same kinetic rate, showing that ripening contributed to changes in the structure of the cheese matrix. Rheological and physicochemical properties were correlated using one of the parameters derived from the power-law model, and the results indicated that correlations improved when MI was included in the model.
\end{abstract}

\section{low-fat soft cheese / viscoelasticity / physicochemical properties / ripening}

摘要 - 脂肪干酪成熟期间的粘弹性变化。本文研究了工业化生产的低脂肪软干酪成熟期间 的粘弹性变化。12 份含有微粒化乳清蛋白 $\left(\right.$ Simpless $\left.^{\circledR}\right)$ 为脂肪代用品的低脂肪软质干酪在 $6{ }^{\circ} \mathrm{C}$ 下它存。其中 3 个样品分别在成熟期的第 $1 、 21 、 48$ 和 $76 \mathrm{~d}$ 取样测定干酪的物理化学 性质, 如 $\mathrm{pH}$ 、水分含量、盐浓度和成熟指数。在 $20{ }^{\circ} \mathrm{C}$ 和 $0.01 \sim 10 \mathrm{~Hz}$ 下进行频率扫描, 根 据扫描强度来测定弹性粘度的线性范围。采用 power-law 和 Maxwell 方程模拟频率与弹性 和粘性模量函数。干酪最初的水分含量为 $52.80 \pm 0.46 \%$, 成熟期间水分含量变化不显著。第 $1 \mathrm{~d}$ 盐浓度为 $0.41 \pm 0.01 \%$, 成熟期间盐浓度显著增加。从第 $1 \mathrm{~d}$ 到第 $48 \mathrm{~d}, \mathrm{pH}$ 从 $5.27 \pm$ 0.03 降到 $5.11 \pm 0.03$, 而成熟指数则从第 $1 \mathrm{~d}$ 的 $3.60 \pm 0.67 \%$ 增加到第 $48 \mathrm{~d}$ 的 $8.66 \pm$ $1.05 \%$ 。在低于 $630 \mathrm{~Pa}$ 应力下的动态试验证明, 含乳清蛋白的低脂干酪表现为线性粘弹性材料。 通常, 在相同的动力学速率下, 从两种模量中推算出的粘弹性参数与成熟时间成反比, 也

*Corresponding author (通讯作者): arubiolo@intec.unl.edu.ar 
就说明了成熟时间决定了干酪基质结构的变化。如果在 power-law 方程中考虑到成熟指数 这个参数, 则从该模型中获得的参数与干酪的流变性和物理化学特性呈相关性。

\section{低脂软干酪 / 粘弹性 / 物理化学特性 / 成熟}

Résumé - Comportement viscoélastique d'un fromage à pâte molle allégé en matière grasse au cours de l'affinage. Le changement intervenant au cours de l'affinage dans le comportement viscoélastique d'un fromage à pâte molle allégé en matière grasse a été étudié. Douze fromages contenant des protéines de lactosérum sous forme de microparticules $\left(\right.$ Simplesse $\left.^{\circledR}\right)$ en remplacement de la matière grasse ont été obtenus auprès d'une firme locale et conservés à $6{ }^{\circ} \mathrm{C}$. Trois de ces fromages ont été prélevés à $1,21,48$ et 76 jours d'affinage. Les propriétés physicochimiques telles que le $\mathrm{pH}$, la teneur en humidité, la concentration en sel et l'index de maturation ont été déterminées. Des balayages de fréquence dans la zone $0,01-10 \mathrm{~Hz}$ ont été réalisés à $20^{\circ} \mathrm{C}$ et la région de viscoélasticité linéaire a été déterminée en réalisant des balayages en contrainte. La dépendance à la fréquence des modules élastique et visqueux a été modélisée par la loi de puissance et les équations de Maxwell. La teneur initiale en humidité était de 52,80 $\pm 0,46 \%$ et ne variait pas de façon significative au cours de l'affinage. La teneur en sel était de $0,41 \pm 0,01 \%$ le $1^{\text {er }}$ jour et augmentait significativement au cours de la maturation. Le $\mathrm{pH}$ diminuait de $5,27 \pm 0,03$ le $1^{\text {er }}$ jour à $5,11 \pm$ 0,03 le $48^{\mathrm{e}}$ jour, tandis que l'index de maturation augmentait de $3,60 \pm 0,67$ le $1^{\text {er }}$ jour à $8,66 \pm$ 1,05 le $48^{\mathrm{e}}$ jour. Le fromage à pâte molle allégé en matière grasse contenant les protéines de lactosérum avait un comportement viscoélastique linéaire au cours du test dynamique à des contraintes inférieures à $630 \mathrm{~Pa}$. En général, les paramètres viscoélastiques dérivés des deux modèles diminuaient au cours de l'affinage et avec la même cinétique, ce qui montre que l'affinage contribuait aux changements de structure de la matrice fromagère. Les propriétés rhéologiques et physico-chimiques étaient corrélées en utilisant un des paramètres dérivés de la loi de puissance et les résultats indiquaient que les corrélations étaient améliorées lorsque l'index de maturation était inclus dans le modèle.

fromage à pâte molle allégé en matière grasse / viscoélasticité / propriété physicochimique / affinage

\section{INTRODUCTION}

Rheological properties obtained in the linear viscoelastic region are useful tools for the food industry. Elastic and viscous contributions to the internal structure of the sample can be obtained performing oscillatory measurements. Such studies provide an insight into the fundamental nature of the physical basis of food texture [2]. Cheese is a typical viscoelastic food whose structure can be considered as a casein network embedded with a dispersed phase of fat globules, minerals and water. The rheological behavior of cheeses is influenced by the components in the cheese matrix structure [19]. Also, the viscoelasticity of cheeses can be influenced by ripening because the structure of the cheese matrix is modified due to breakdown of the protein network during casein hydrolysis. During ripening, the changes in $\mathrm{pH}$, moisture content and salt concentration can affect textural characteristics of cheeses [17]. For this reason, correlations between rheological parameters and physicochemical properties of cheeses over ripening of commercial cheeses have been reported [2, 5, 24].

Over the last decade, the production of low-fat cheeses has significantly increased. However, the removal of fat from the cheese has been shown to cause textural, functional and sensory defects. The use of fat mimetics in the cheesemaking process is an interesting strategy to improve the quality of lowfat cheeses [13]. Protein-based fat mimetics, such as Simplesse ${ }^{\circledR}$ or Dairy-Lo ${ }^{\mathrm{TM}}$, consisting of microparticles of whey proteins have the property to give a sense of creaminess similar to fat [16]. 
Changes in some textural parameters (hardness, fracturability and chewiness) over ripening of several types of low-fat cheeses manufactured with Simplesse ${ }^{\circledR}$ and DairyLo $^{\text {TM }}$ were published [7, 14, 15], but few studies about viscoelastic properties of those kinds of cheese have been reported [11, 25]. Moreover, viscoelastic behavior during a specified ripening period of a low-fat soft cheese containing Simplesse ${ }^{\circledR}$ has not been extensively studied.

The objective of this work was to study the change in the viscoelastic behavior during ripening of a commercial low-fat soft cheese containing whey proteins (Simplesse ${ }^{\circledR}$ ) and to find the relationships between some rheological parameters and physicochemical properties.

\section{MATERIALS AND METHODS}

\subsection{Cheese samples}

Twelve low-fat soft cheeses (LFSC) that contained whey proteins as fat mimetics (Simplesse $^{\circledR}$ D100, NutraSweet Co., Deerfield, IL, USA) were used for this study. Cheeses were manufactured at a local factory according to regional legislation [3], obtained by rennet coagulation of pasteurized skim milk, salted in brine to reach a final salt concentration of $0.41 \pm 0.01 \%$ and packed in heat-shrinkable plastic bags. Cheese samples had a rectangular shape $(28.7 \pm 0.3 \mathrm{~cm} \times 11.6 \pm 0.3 \mathrm{~cm} \times 7.4 \pm$ $0.2 \mathrm{~cm})$ and a weight of $3.0 \pm 0.1 \mathrm{~kg}$. Cheeses were transported in ice containers from the factory to the laboratory and were stored in a Tabai Comstar PR 4GM chamber (Tabai Espec Corp., Osaka, Japan) at $6{ }^{\circ} \mathrm{C}$. Cheeses were sampled at different ripening times $(1,21,48$ and 76 days) in triplicate. Four slices (3 cm thickness) parallel to the smallest surface $(11.6 \pm 0.3 \mathrm{~cm} \times 7.4 \pm$ $0.2 \mathrm{~cm}$ ) were obtained from the central zone of the cheeses. A thin layer was removed from slices, leaving an area of $9 \mathrm{~cm} \times 6 \mathrm{~cm}$ and $3 \mathrm{~cm}$ thickness for sampling. Subsequently, six cubes of $3 \mathrm{~cm}$ side were obtained for each slice but only four cubes near each corner were used as samples. Finally, slices of $3 \mathrm{~mm}$ were cut from the cubes. Both cubes and slices were stored in plastic containers, to prevent dehydration, and held refrigerated until physicochemical and rheological testing.

\subsection{Physicochemical analysis}

Moisture content was measured with a microwave oven CEM AVC 80 (CEM, Attheus, NC, USA) according to the Association of Official Analytical Chemists procedure [1]. The initial fat content $(5.75 \pm$ $0.04 \%$ ) was determined in duplicate using the standard method of International Dairy Federation [6]. Salt concentration was determined as proposed by Fox [4] with an automatic titrator model DL40RC (Mettler Instrumente AG, Greifensee, Switzerland). The $\mathrm{pH}$ was measured with an electrode for solid foods $(\mathrm{pH}$ Spear, OAKTON Instruments, Vernon Hills, IL, USA). Water-soluble fraction was extracted with a procedure developed by Kuchroo and Fox [8], and modified by Verdini and Rubiolo [24]. Total nitrogen content (TN) and water-soluble nitrogen content (WSN) were determined using the micro-Kjeldahl method with an automatic digestor model 430, a distillation unit model 322 (Büchi, Flawil, Switzerland) and the automatic titrator. Maturation index (MI) was expressed as a percentage of the $\mathrm{WSN}$ to the TN $(\mathrm{MI}=\mathrm{WSN} \times 100 / \mathrm{TN})$. Two replicates were used in all analysis.

\subsection{Rheological analysis}

\subsubsection{Stress and frequency sweeps}

Disks (20 mm of diameter) were cut with a borer from the cheese slices and were used for the rheological analysis. Frequency sweeps were performed in the range of $0.01-10 \mathrm{~Hz}$ at $20.0 \pm 0.5^{\circ} \mathrm{C}$ using a stress 
controlled rheometer RheoStress 80 (Haake Inc. Instruments, Karlsruhe, Germany) with a plate-plate geometry test fixture. Diameter and gap were 20 and $2.5 \mathrm{~mm}$, respectively. The region of linear viscoelasticity was determined prior to each frequency sweep performing stress sweeps at $10 \mathrm{~Hz}$. A thin film of silicone oil (100 cp) was applied to the exposed sample edges to prevent water evaporation during measurements. Elastic $\left(G^{\prime}\right)$, viscous $\left(G^{\prime \prime}\right)$ and complex $\left(\left|G^{*}\right|\right)$ moduli, complex viscosity $\left(\left|\eta^{*}\right|\right)$ and tangent of phase angle $(\tan \delta)$ were measured at a fixed stress amplitude (318 Pa). Frequency sweeps were conducted in duplicate for each sample.

\subsubsection{Modeling of the mechanical spectra}

Frequency dependence of $G^{\prime}$ and $G^{\prime \prime}$ was modeled with power-law equations (1) and (2) and Maxwell equations (3) and (4) [18]:

$$
\begin{gathered}
G^{\prime}(\omega)=a \omega^{x}, \\
G^{\prime \prime}(\omega)=b \omega^{y}, \\
G^{\prime}(\omega)=\sum_{i=1}^{n} \frac{G_{i}\left(\omega \lambda_{i}\right)^{2}}{1+\omega^{2} \lambda_{i}^{2}}, \\
G^{\prime \prime}(\omega)=\sum_{i=1}^{n} \frac{G_{i} \omega \lambda_{i}}{1+\omega^{2} \lambda_{i}^{2}},
\end{gathered}
$$

where $\omega$ is the frequency, $a, b, x$ and $y$ are the power-law parameters, $\lambda_{i}$ is the relaxation time and $G_{i}$ is the relaxation modulus of the $i^{\text {th }}$ Maxwell element, respectively.

\subsubsection{Kinetic analysis of the rheological parameters}

A first-order kinetic model was assumed to represent the behavior of the rheological parameters derived from power-law and Maxwell equations during the ripening time [24]:

$$
P(\theta)=P_{0} \mathrm{e}^{-K \theta}
$$

where $P_{0}$ is the initial value of the rheological parameter, $P(\theta)$ is the rheological parameter over ripening, $\theta$ is the ripening time expressed in days (d) and $K$ is the kinetic rate constant $\left(\mathrm{d}^{-1}\right)$.

\subsection{Statistical analysis}

Analysis of variance was performed and when the effect of the factors was significant $(P<0.05)$, the multiple ranks HSD Tukey test was applied (95\% of confidence level). Linear regression was used to determine the corresponding parameters of power-law equation. Nonlinear regression analysis was conducted to obtain the parameters of five Maxwell elements, using the procedure proposed by Subramanian et al. [20]. Multiple regression analysis was applied in order to establish the relationships between rheological parameters and physicochemical properties. The complete statistical analysis was performed using Minitab 13.20 (Minitab Inc., State College, PA, USA).

\section{RESULTS AND DISCUSSION}

\subsection{Physicochemical analysis}

The initial moisture content of the LFSC was $52.80 \pm 0.46 \%$, and the moisture content did not change significantly during the studied ripening period (Tab. I). The high moisture content observed in LFSC is in agreement with the reports of other authors in several types of low-fat cheeses containing whey protein-based fat mimetics $[7,12$, 14, 15]. Fat mimetics are known for their water-binding capacity, which may in turn explain the higher moisture content found in cheeses containing these materials [14]. 
Table I. Physicochemical properties over the ripening of a commercial low-fat soft cheese containing whey proteins.

\begin{tabular}{lccccr}
\hline $\begin{array}{l}\text { Ripening time } \\
\text { (days) }\end{array}$ & $\begin{array}{c}\text { Moisture } \\
(\% \mathrm{w} / \mathrm{w})^{1}\end{array}$ & $\mathrm{pH}^{1}$ & $\begin{array}{c}\text { Salt } \\
(\% \mathrm{w} / \mathrm{w})^{1}\end{array}$ & $\begin{array}{c}\text { Proteins } \\
(\% \mathrm{w} / \mathrm{w})^{1}\end{array}$ & $\begin{array}{c}\text { Maturation } \\
\text { index }^{1}\end{array}$ \\
\hline 1 & $52.80 \pm 0.46^{\mathrm{a}}$ & $5.27 \pm 0.03^{\mathrm{b}}$ & $0.41 \pm 0.00^{\mathrm{a}}$ & $33.58 \pm 0.01$ & $3.60 \pm 0.67^{\mathrm{a}}$ \\
21 & $52.26 \pm 0.68^{\mathrm{a}}$ & $5.18 \pm 0.05^{\mathrm{ab}}$ & $0.71 \pm 0.05^{\mathrm{b}}$ & $33.31 \pm 1.17$ & $6.62 \pm 0.21^{\mathrm{b}}$ \\
48 & $51.76 \pm 0.59^{\mathrm{a}}$ & $5.11 \pm 0.03^{\mathrm{a}}$ & $0.76 \pm 0.14^{\mathrm{b}}$ & $33.26 \pm 0.40$ & $8.66 \pm 1.05^{\mathrm{c}}$ \\
76 & $52.43 \pm 0.29^{\mathrm{a}}$ & $5.16 \pm 0.04^{\mathrm{a}}$ & $0.69 \pm 0.13^{\mathrm{b}}$ & $33.42 \pm 1.39$ & $10.24 \pm 0.54^{\mathrm{c}}$ \\
\hline
\end{tabular}

${ }^{1}$ Mean values and standard deviations of three samples.

${ }^{\mathrm{a}-\mathrm{c}}$ Mean values within a column with the same letter are not significantly different $(P<0.05)$.

Also, it has been suggested that these materials interfere with the shrinkage of the casein matrix, retarding the curd syneresis during the cheesemaking process [12]. However, moisture content of LFSC did not change significantly during the studied ripening period (Tab. I).

The initial salt concentration of the LFSC was $0.41 \pm 0.01 \%$, and it increased significantly over ripening from 1 to 21 days and did not change significantly between 21 and 76 days (Tab. I). This result is expected because when cheeses are salted in brine, salt gradient develops from the surface to the center of the cheese, leading to an almost uniform salt distribution [10].

The initial $\mathrm{pH}$ of the LFSC was $5.27 \pm 0.03$, and the $\mathrm{pH}$ slightly decreased during ripening from 1 to 48 days and did not change significantly between 48 and 76 days (Tab. I). Residual lactose in cheese is fermented by lactic acid bacteria to several water-soluble organic acids. Upon dissociation, organic acids liberate $\mathrm{H}^{+}$, causing a decrease in $\mathrm{pH}$. Buffering in cheese is related to the presence of proteins and inorganic constituents such as weak acids, bases and metal ion complexes [9]. The production of acid should lead to immediate solubilization of calcium and phosphate entrapped by the para-casein network, which would act as a buffer resisting the decrease in the $\mathrm{pH}$ [21].
MI of the LFSC increased significantly over ripening, from $3.60 \pm 0.67 \%$ at the beginning of the maturation to $8.66 \pm$ $1.05 \%$ at 48 days of ripening, but there were no significant differences between 48 and 76 days (Tab. I). The $\mathrm{pH}$ 4.6-soluble nitrogen content is an index of cheese primary proteolysis, which is more prominent during the first weeks of ripening. Subsequent hydrolysis of the large and intermediate-sized peptides results in the formation of smaller peptides and free amino acids that does not significantly influence $\mathrm{pH}$ 4.6-soluble nitrogen content [17]. Hence, larger changes in the $\mathrm{pH}$ 4.6-soluble nitrogen content are expected during the initial stages of ripening compared with the later stages [22].

\subsection{Rheological analysis}

\subsubsection{Region of linear viscoelasticity}

Values of $\left|G^{*}\right|$ and strain $(\gamma)$ of the LFSC were plotted as a function of applied stress at the frequency of $10 \mathrm{~Hz}$ (Fig. 1). At any ripening time, values of $\left|G^{*}\right|$ were not affected by the magnitude of the applied stress and a linear relationship between stress and strain was observed. The linear relationship between stress and strain in the experimental conditions indicates that regardless of structural changes during ripening, LFSC behaved as a linear viscoelastic material 


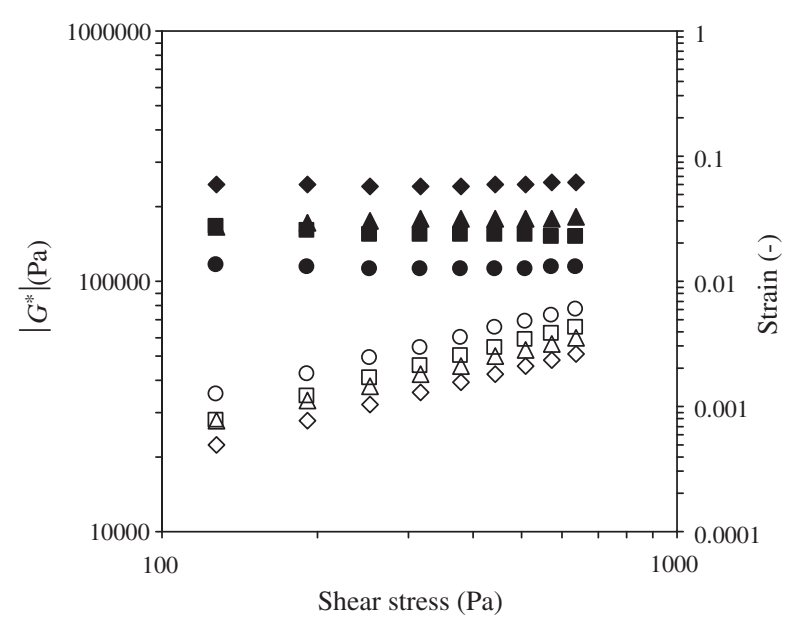

Figure 1. Stress sweeps over the ripening of a commercial low-fat soft cheese containing whey proteins. Full symbols complex modulus $\left(\left|G^{*}\right|\right)$ and empty symbols strain $(\gamma)$ : $(\bullet)$ day $1,(\boldsymbol{\Delta} \Delta)$ day $21,(\bullet)$ day 48 and $(\bullet \circ)$ day 76 of ripening. Points represent individual values of one of two replications.

during dynamic testing at stresses below $630 \mathrm{~Pa}$.

\subsubsection{Mechanical spectra}

Changes in $G^{\prime}$ and $G^{\prime \prime}$ of the LFSC as a function of frequency are shown in Figure 2. Elastic modulus was greater than viscous modulus throughout the frequency range, indicating that LFSC showed a solid-like behavior at any ripening time. This mechanical spectrum describes the characteristic behavior of a viscoelastic solid [18].

Changes in $\left|G^{*}\right|$ and $\left|\eta^{*}\right|$ of the LFSC as a function of frequency are shown in Figure 3. Values of $\left|G^{*}\right|$ and $\left|\eta^{*}\right|$ describe the total resistance to deformation of a material that is considered as an elastic solid or a viscous liquid. Complex modulus increased and complex viscosity decreased with frequency, showing the same pattern of viscoelastic response at any ripening time.

Values of $\tan \delta$, that compares the amount of energy lost to the amount of energy stored during a test cycle, are shown in Figure 4. According to Gravier et al. [5], $\tan \delta$ can be used to indicate the strong relationship between the viscous behavior and the degree of casein hydrolysis. Values of $\tan \delta$ of LFSC were between 0.3 and 0.55 , indicating that elastic properties predominate at any ripening time. However, values of $\tan \delta$ increased with the ripening time, showing that viscous properties increased over ripening.

\subsubsection{Modeling of the mechanical spectra}

Power-law and Maxwell parameters of LFSC are shown in Tables II and III, respectively. Coefficients $a$ and $b$ represent the magnitude of $G^{\prime}$ and $G^{\prime \prime}$ at a frequency of $1 \mathrm{rad} \cdot \mathrm{s}^{-1}$, and exponents $x$ and $y$ represent the slopes of the linear relationships between modulus and frequency. Coefficient $a$ was higher than $b$, showing the predominance of a solid-like behavior at any ripening time. Also, exponent $x$ was higher than exponent $y$, indicating that elastic properties were more sensitive to frequency changes than viscous properties. 


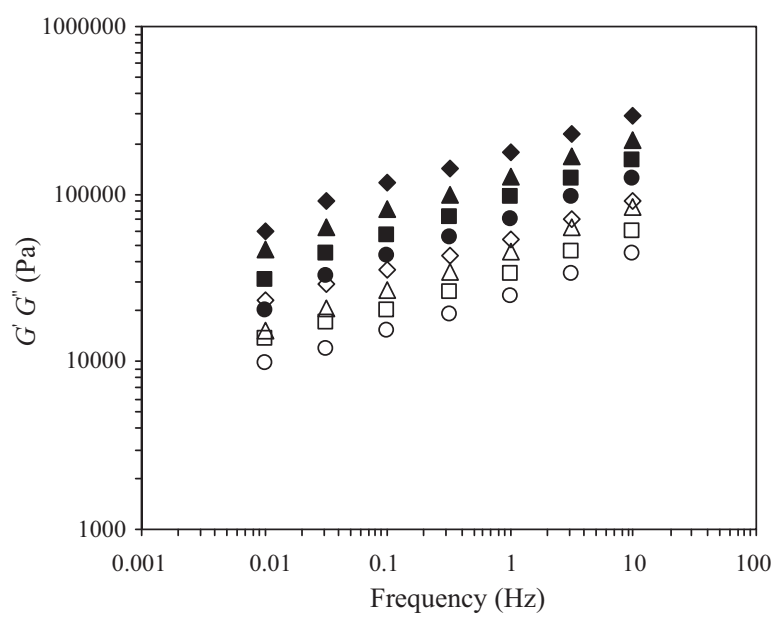

Figure 2. Frequency sweeps over the ripening of a commercial low-fat soft cheese containing whey proteins. Full symbols elastic modulus $\left(G^{\prime}\right)$ and empty symbols viscous modulus $\left(G^{\prime \prime}\right):(\diamond)$ day $1,(\Delta \Delta)$ day $21,(\bullet \square)$ day 48 and $(\bullet \circ)$ day 76 of ripening. Points represent individual values of one of two replications.

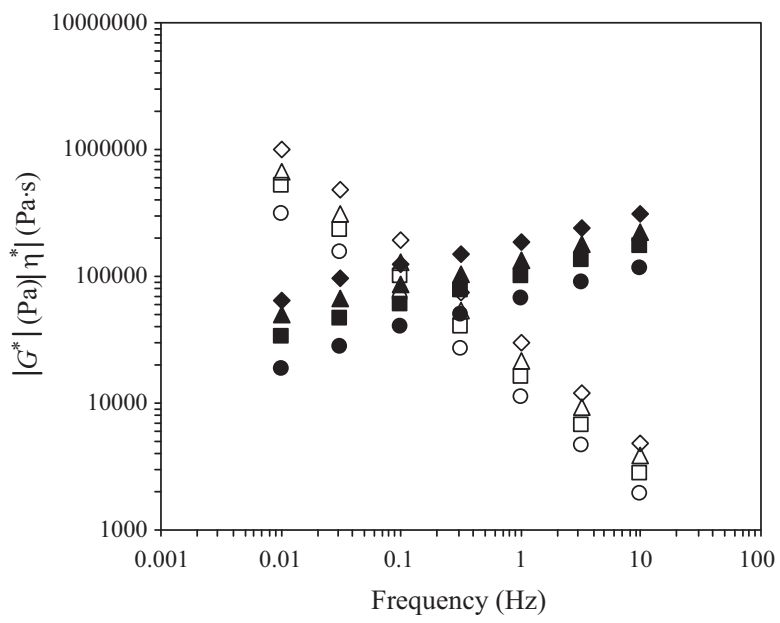

Figure 3. Complex modulus $\left(\left|G^{*}\right|\right)$ and complex viscosity $\left(\left|\eta^{*}\right|\right)$ over the ripening of a commercial low-fat soft cheese containing whey proteins. Full symbols $\left|G^{*}\right|$ and empty symbols $\left|\eta^{*}\right|:(\diamond)$ day 1 , $(\Delta \Delta)$ day $21,(\bullet)$ day 48 and $(\bullet \circ)$ day 76 of ripening. Points represent individual values of one of two replications.

During cheese ripening, coefficients $a$ and $b$ decreased, while exponents $x$ and $y$ increased with ripening time. This result indicates that both elastic and viscous components were sensitive to frequency changes during maturation. These observations are 


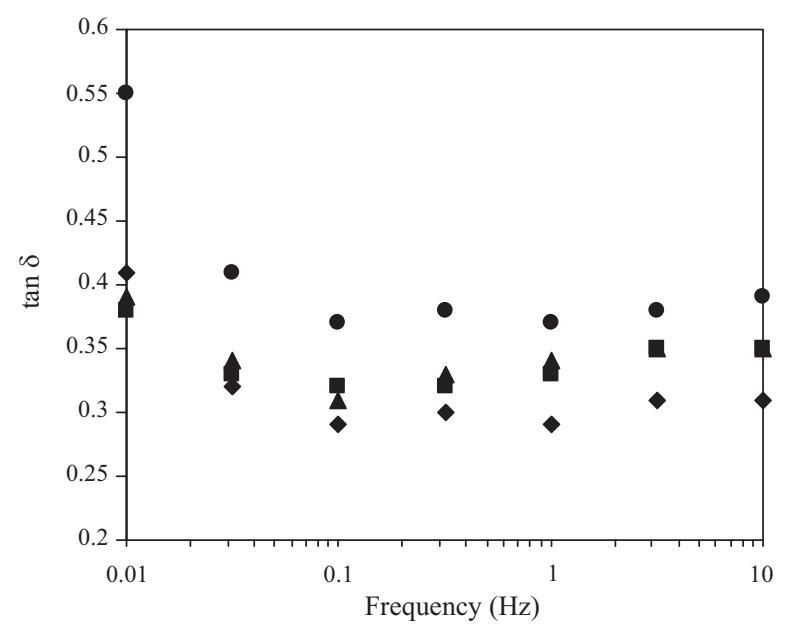

Figure 4. Tangent of phase angle $(\tan \delta)$ over the ripening of a commercial low-fat soft cheese

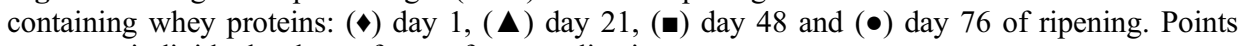
represent individual values of one of two replications.

Table II. Power-law parameters for elastic $\left(G^{\prime}=a \omega^{x}\right)$ and viscous $\left(G^{\prime \prime}=b \omega^{\mathrm{y}}\right)$ moduli over the ripening of a commercial low-fat soft cheese containing whey proteins.

\begin{tabular}{|c|c|c|c|c|c|c|}
\hline \multirow{2}{*}{$\begin{array}{l}\text { Ripening time } \\
\text { (days) }\end{array}$} & \multicolumn{3}{|c|}{$G^{\prime}$} & \multicolumn{3}{|c|}{$G^{\prime \prime}$} \\
\hline & $a(\mathrm{kPa} \cdot \mathrm{s})^{1}$ & $x^{1}$ & $R^{2}$ & $b(\mathrm{kPa} \cdot \mathrm{s})^{1}$ & $y^{1}$ & $R^{2}$ \\
\hline 1 & $121.1 \pm 5.2^{\mathrm{a}}$ & $0.217 \pm 0.001^{\mathrm{a}}$ & 0.99 & $39.5 \pm 1.5^{\mathrm{a}}$ & $0.185 \pm 0.002^{\mathrm{a}}$ & 0.99 \\
\hline 21 & $79.2 \pm 16.1^{b}$ & $0.231 \pm 0.011^{\mathrm{ab}}$ & 0.99 & $28.8 \pm 5.5^{\mathrm{b}}$ & $0.210 \pm 0.011^{\mathrm{b}}$ & 0.99 \\
\hline 48 & $72.1 \pm 10.6^{\mathrm{b}}$ & $0.236 \pm 0.008^{\mathrm{ab}}$ & 0.99 & $25.6 \pm 3.5^{\mathrm{bc}}$ & $0.233 \pm 0.008^{\mathrm{b}}$ & 0.99 \\
\hline 76 & $43.9 \pm 4.5^{\mathrm{c}}$ & $0.248 \pm 0.017^{\mathrm{b}}$ & 0.99 & $17.7 \pm 1.5^{\mathrm{c}}$ & $0.215 \pm 0.011^{\mathrm{b}}$ & 0.99 \\
\hline
\end{tabular}

${ }^{1}$ Mean values and standard deviations of three samples.

${ }^{\mathrm{a}-\mathrm{c}}$ Mean values within a column with the same letter are not significantly different $(P<0.05)$.

in agreement with the decrease in the cheese matrix rigidity during ripening.

In general, the elastic contribution of each Maxwell element $\left(G_{i}\right)$ decreased as the ripening time increased. These results are expected because cheese becomes softer during ripening [19]. The proteolysis during ripening contributes to the softening of cheese because most casein breakdown products are water soluble and they cannot contribute to the framework provided by the protein matrix [23].

\subsubsection{Kinetic analysis of rheological parameters}

The behavior of the rheological parameters of the LFSC during the ripening time is shown in Figure 5. In order to establish the rate of decay of parameters $a$ and $b$ derived from power-law equation and parameters $G_{i}$ derived from Maxwell equation, kinetic rate constants were calculated (Fig. 5). These obtained results indicate that all parameters decreased with the same rate $(P>0.05)$ 
Table III. Parameters derived from Maxwell model $\left(\lambda_{i}\right.$ and $G_{i}$ for $\left.i=1, \ldots, 5\right)$ over the ripening of a commercial low-fat soft cheese containing whey proteins.

\begin{tabular}{|c|c|c|c|c|c|c|}
\hline $\begin{array}{l}\text { Ripening time } \\
\text { (days) }\end{array}$ & $\frac{\lambda_{1}=0.01 \mathrm{~s}^{1}}{G_{1}(\mathrm{~Pa})^{2,3}}$ & $\frac{\lambda_{2}=0.1 \mathrm{~s}^{1}}{G_{2}(\mathrm{~Pa})^{2,3}}$ & $\begin{array}{l}\lambda_{3}=1 \mathrm{~s}^{1} \\
G_{3}(\mathrm{~Pa})^{2,3}\end{array}$ & $\frac{\lambda_{4}=10 \mathrm{~s}^{1}}{G_{4}(\mathrm{~Pa})^{2,3}}$ & $\frac{\lambda_{5}=100 \mathrm{~s}^{1}}{G_{5}(\mathrm{~Pa})^{2,3}}$ & $R^{2}$ \\
\hline 1 & $177.4 \pm 7.7^{\mathrm{a}}$ & $83.4 \pm 5.7^{\mathrm{a}}$ & $56.6 \pm 3.9^{\mathrm{a}}$ & $57.9 \pm 1.2^{\mathrm{a}}$ & $31.5 \pm 2.9^{\mathrm{a}}$ & 0.99 \\
\hline 21 & $134.5 \pm 17.9^{\mathrm{a}}$ & $60.8 \pm 6.8^{\mathrm{b}}$ & $38.6 \pm 7.9^{\mathrm{b}}$ & $34.1 \pm 7.0^{\mathrm{b}}$ & $29.4 \pm 7.0^{\mathrm{b}}$ & 0.99 \\
\hline 48 & $125.9 \pm 13.0^{\mathrm{a}}$ & $58.1 \pm 10.7^{b}$ & $30.1 \pm 4.5^{\mathrm{bc}}$ & $21.9 \pm 3.9^{\mathrm{bc}}$ & $28.9 \pm 4.8^{\mathrm{b}}$ & 0.99 \\
\hline 76 & $77.7 \pm 10.5^{b}$ & $38.0 \pm 3.0^{\mathrm{c}}$ & $23.1 \pm 1.5^{\mathrm{c}}$ & $20.7 \pm 1.8^{\mathrm{c}}$ & $14.3 \pm 3.1^{\mathrm{c}}$ & 0.99 \\
\hline
\end{tabular}

${ }^{1}$ Relaxation time of the $i^{\text {th }}$ Maxwell element.

2 Relaxation modulus of the $i^{\text {th }}$ Maxwell element.

${ }^{3}$ Mean values and standard deviations of three samples.

${ }^{\mathrm{a}-\mathrm{c}}$ Mean values with the same letter for each Maxwell element within a column are not significantly different $(P<0.05)$.

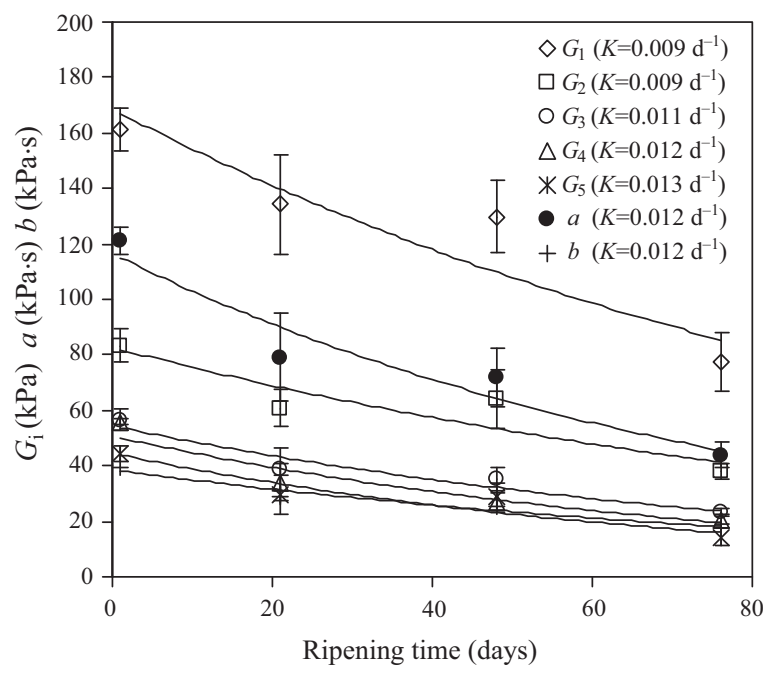

Figure 5. Decay of rheological parameters obtained from power-law and Maxwell equations as a function of ripening time of a commercial low-fat soft cheese containing whey proteins. Lines represent fitted curves.

during the studied ripening period. In addition, both models appropriately characterized the mechanical spectra of LFSC over ripening (Tabs. II and III). For this reason, parameter $a$ of power-law equation was arbitrarily selected to correlate physicochemical properties and rheological parameters.

\subsubsection{Correlation between physicochemical properties and rheological parameter a}

Correlations between physicochemical properties (salt concentration, $\mathrm{pH}$ and $\mathrm{MI}$ ) and the rheological parameter $a$ of powerlaw equation are shown in Table IV. 
Table IV. Correlations between physicochemical properties and rheological parameter $a$ of powerlaw equation over the ripening of a commercial low-fat soft cheese with whey proteins.

\begin{tabular}{lr}
\hline Regression equation $^{1}$ & $R^{2}$ \\
\hline$a=153.48-10.22 \times \mathrm{MI}$ & 0.81 \\
$a=-1471.85+299.31 \times \mathrm{pH}$ & 0.50 \\
$a=154.58-117.82 \times \mathrm{NaCl}$ & 0.42 \\
$a=-156.66+58.30 \times \mathrm{pH}-9.11 \times \mathrm{MI}$ & 0.82 \\
$a=-1005.74+215.36 \times \mathrm{pH}-48.5 \times \mathrm{NaCl}$ & 0.53 \\
$a=-311.24+26.62 \times \mathrm{NaCl}+85.82 \times \mathrm{pH}-9.81 \times \mathrm{MI}$ & 0.83 \\
\hline
\end{tabular}

${ }^{1}$ MI: maturation index.

The best simple correlation was obtained between MI and $a$. The negative correlation indicates that when MI increased the rheological parameter $a$ decreased. This observation reaffirms the importance of proteins in cheese texture that was previously published by other authors $[2,5,24]$. The proteolysis of LFSC produced an increase in the $\mathrm{pH} 4.6$-soluble nitrogen compounds that cannot contribute to the protein network. This behavior is related to a decrease in the cheese matrix rigidity that becomes softer during ripening.

The combination of MI with other physicochemical properties such as moisture content, salt concentration and $\mathrm{pH}$ using multiple correlations did not improve the results obtained when MI was used alone (Tab. IV).

\section{CONCLUSIONS}

This study allowed the characterization of the change in the viscoelastic behavior over ripening of a commercial low-fat soft cheese that contained whey proteins as fat mimetics $\left(\right.$ Simplesse $\left.{ }^{\circledR}\right)$. This cheese behaved as a linear viscoelastic material during dynamic testing at stresses below $630 \mathrm{~Pa}$ and also, elastic properties predominated in the mechanical spectra. In general, viscoelastic parameters derived from power-law and Maxwell equations decreased with the ripening time and decayed with the same kinetic rate, showing that ripening contributed to changes in the structure of cheese matrix. The best correlation between physicochemical properties and rheological parameters was obtained between parameter $a$ derived from the power-law equation and MI. The resulted regression equation can be used to predict the MI from rheological tests.

Acknowledgements: This work was done with the financial support of Universidad Nacional del Litoral, Consejo Nacional de Investigaciones Científicas y Técnicas and the Agencia Nacional de Promoción Científica y Tecnológica of Argentina. The authors acknowledge Daniel De Piante Vicin for technical assistance in the rheological tests and physicochemical determinations.

\section{REFERENCES}

[1] AOAC, Moisture in Cheese, AOAC Official Method 977.11. Official Methods of Analysis: Food Composition; Additives; Natural Contaminants (Vol. II), Association of Official Analytical Chemists Inc., USA, 1990.

[2] Bertola N.C., Bevilacqua A.E., Zaritzky N.E., Proteolytic and rheological evaluation of maturation of Tybo Argentino cheese, J. Dairy Sci. 75 (1992) 3273-3281.

[3] CAA, Código Alimentario Argentino, Capítulo VIII: Alimentos Lácteos, available at: http://www.anmat.gov.ar, 2006.

[4] Fox P.F., Potentiometric determination of salt in cheese, J. Dairy Sci. 46 (1963) 744-745. 
[5] Gravier N.G., Zaritzky N.E., Califano A.N., Viscoelastic behavior of refrigerated and frozen low-moisture Mozzarella cheese, J. Food Sci. 9 (2004) 123-128.

[6] IDF, Determination of the Fat Content of Cheese and of Processed Cheese Products, IDF Standard 5A, International Dairy Federation, Brussels, Belgium, 1969.

[7] Koca N., Metin M., Textural, melting and sensory properties of low-fat fresh Kashar cheeses produced by using fat replacers, Int. Dairy J. 14 (2004) 365-373.

[8] Kuchroo C.N., Fox P.F., Soluble nitrogen in Cheddar cheese: comparison of extraction procedures, Milchwissenschaft 37 (1982) 331-335.

[9] Lucey J.A., Fox P.F., Importance of calcium and phosphate in cheese manufacture: a review, J. Dairy Sci. 76 (1993) 1714-1724.

[10] Luna J.A., Chavez M.S., Mathematical model for water diffusion during brining of hard and semi-hard cheese, J. Food Sci. 57 (1992) 55-58.

[11] Ma L., Barbosa-Canovas G.V., Swanson B.G., Rheology of full-fat and low-fat Cheddar cheeses as related to type of fat mimetic, J. Food Sci. 62 (1997) 748-752.

[12] McMahon D.J., Alleyne M.C., Fife R.L., Oberg C.J., Use of fat replacers in low fat Mozzarella cheese, J. Dairy Sci. 79 (1996) 1911-1921.

[13] Mistry V.V., Low fat cheese technology, Int. Dairy J. 11 (2001) 413-422.

[14] Romeih E.A., Michaelidou A., Biliaderis C.G., Zerfiridis G.K., Low-fat white-brined cheese made from bovine milk and two commercial fat mimetics: chemical, physical and sensory attributes, Int. Dairy J. 12 (2002) 525-540.

[15] Sahan N., Yasar K., Hayaloglu A.A, Karaca O.B., Kaya A., Influence of fat replacers on chemical composition, proteolysis, texture profiles, meltability and sensory properties of low-fat Kashar cheese, J. Dairy Res. 75 (2008) 1-7.
[16] Singer S.N., Microparticulated proteins as fat mimetics, in: Roller S., Jones S.A. (Eds.), Handbook of Fat Replacers, CRC Press, Boca Raton, New York, USA, 1996.

[17] Sousa M.J., Ardö Y., McSweeney P.L.H., Advances in the study of proteolysis during cheese ripening, Int. Dairy J. 11 (2001) $327-345$.

[18] Steffe J.F., Rheological Methods in Food Process Engineering, Freeman Press, East Lansing, USA, 1992.

[19] Subramanian R., Gunasekaran S., Small amplitude oscillatory shear studies on Mozzarella cheese. Part II. Relaxation spectrum, J. Texture Stud. 28 (1997) 643-656.

[20] Subramanian R., Muthukumarappan K., Gunasekaran S., Linear viscoelastic properties of regular and reduced-fat pasteurized process cheese during heating and cooling, Int. J. Food Prop. 9 (2006) 377-393.

[21] Upreti P., Metzger L.E., Influence of calcium and phosphorus, lactose and salt-to-moisture ratio on Cheddar cheese quality: $\mathrm{pH}$ changes during ripening, J. Dairy Sci. 90 (2007) $1-12$.

[22] Upreti P., Metzger L.E., Hayes K.D., Influence of calcium and phosphorus, lactose and salt-to-moisture ratio on Cheddar cheese quality: proteolysis during ripening, J. Dairy Sci. 89 (2006) 444-453.

[23] Ustunol Z., Kawachi K., Steffe J., Rheological properties of Cheddar cheese as influenced by fat reduction and ripening time, J. Food Sci. 60 (1995) 1208-1210.

[24] Verdini R.A., Rubiolo A.C., Texture changes during the ripening of Port Salut Argentino cheese in 2 sampling zones, J. Food Sci. 67 (2002) 1808-1813.

[25] Zalazar C.A., Bernal S., Bertola N., Bevilacqua A., Zaritzky N., Effect of moisture level and fat replacer on physicochemical, rheological and sensory properties of low fat soft cheeses, Int. Dairy J. 12 (2002) $45-50$. 